\title{
TUJUAN DAN KRITERIA PERENCANAAN ASUHAN \\ KEPERAWATAN DI RUMAH SAKIT
}

\author{
Icha dameyanti Br Sebayang \\ Email: ichasebayang123@gmail.com
}

\section{Latar Belakang}

Rumah sakit merupakan sebuah organisasi kesehatan yang sangat bermanfaat guna memberikan pelayanan kesehatan bagi masyarakat, sebagaimana tertera dalam UU RI No 44 pasal 1 (2009, p.2). Setiap tenaga kesehatan yang bekerja dirumah sakit harus bekerja sesuai dengan standar profesi, standar pelayanan rumah sakit, standar prosedur operasional yang berlaku, etika profesi, menghormati hak pasien, dan mengutamakan keselamatan pasien. Tenaga kesehatan tersebut diantaranya tenaga medis dan penunjang medis, tenaga keperawatan, tenaga kefarmasian, tenaga manajemen rumah sakit dan tenaga non kesehatan UU RI No 44 pasal 12-13 (2009, p.11-12).

Salah satu pelayanan kesehatan yang diberikan oleh tenaga kesehatan adalah pelayanan keperawatan, Sebagai bagian dari pelayanan kesehatan, maka pelayanan keperawatan yang dilakukan oleh tenaga perawatmemiliki tugas diataranya memberikan asuhan keperawatan (Hidayat, 2011, p.75).

Asuhan keperawatan adalah suatu pendekatan untuk pemecahan masalah yang memampukan perawat untuk mengatur dan memberikan asuhan keperawatan. Standar asuhan yang tercantum dalam Standar Praktik Klinis Keperawatan terdiri dari lima fase asuhan keperawatan: 1) Pengkajian; 2) Diagnosa; 3) Perencanaan; 4) Implementasi; dan 5) Evaluasi. Salah satu manfaat dari penerapan asuhan keperawatan yang baik adalah meningkatkan mutu dan kualitas pelayanan dalam bidang keperawatan (Kozier, 2010). Menurut Sumijatun (2010, p.88) permasalahan pelayanan keperawatan di negara Indonesia adalah banyaknya perawat yang belum melakukan asuhan keperawatan sesuai dengan standar.

Di sebagian besar tatanan pelayanan keperawatan, masih terbatas melakukan kegiatankegiatan yang belum memenuhi kaedah asuhan keperawatan secara profesional yang bertanggung gugat. Penelitian Wirawan (2000) dalam Wahyuni (2015) tentang tingkat kepuasan 
pasien rawat inap terhadap asuhan keperawatan di sebuah rumah sakit di Jawa Timur menunjukkan hanya $17 \%$ pasien rawat inap yang mengatakan puas terhadap asuhan keperawatan, sedangkan $83 \%$ menyatakan tidak puas.

Penelitian tersebut juga memberikan informasi bahwa keluhan utama pasien terhadap pelayanan keperawatan adalah kurangnya komunikasi perawat (80\%), kurang perhatian $(66,7 \%)$ dan kurang ramah $(33,3 \%)$.

Khusus terhadap kinerja perawat, keluhan terbesar adalah perawat jarang menengok pasien bila tidak diminta dan bila dipanggil tidak segera datang perawat datang sekitar 10 menit, Wahyuni (2015).

\section{Metode}

bersifat deskriptif yaitu untuk mengetahui gambaran kelengkapan pendokumentasian asuhan keperawatan pasien di ruang rawat inap Rumah Sakit Tampan Pekanbaru, dengan melakukan studi dokumentasi asuhan keperawatan pasien yang telah menjalani rawatan selama bulan Januari 2009. Penelitian ini dilakukan dengan cara mengambil seluruh sampel status pasien atau rekam medis pasien yang dirawat pada bulan Januari 2009, dengan jumlah sampel seluruhnya adalah 90 berkas, dengan syarat pasien bukan rawatan ulangan di bulan yang sama. Alat yang digunakan dalam penelitian ini adalah Standar Asuhan Keperawatan Depkes RI tahun 1997. Adapun cara penilaian penggunaan instrumen dalam penelitian ini adalah bila aspek yang dinilai sesuai dengan Standar Asuhan keperawatan maka diberi tanda "V" dan apabila aspek yang dinilai tidak sesuai dengan Standar Asuhan keperawatan maka diberi tanda "C"

\section{Hasil dan pembahasan}

Pelaksanaan asuhan keperawatan oleh seorang perawat merupakan tindakan yang sangat penting peranannya dalam membantu klien menyelesaikan masalah kesehatannya. Perilaku caring, humanistik, dan holistik harus selalu mendasari perilaku perawat dalam memberikan asuhan keperawatan yang profesional kepada klien. Seperti yang ditekankan oleh Chitty (dalam 
Nursalam 2002) bahwa nilai-nilai ilmu keperawatan ditekankan pada tiga unsur utama, yaitu: holistik, humanistik, dan care Sedangkan distribusi frekuensi kinerja perawat dalam pendokumentasian asuhan keperawatan, diketahui bahwa lebih dari setengah responden memiliki kinerja asuhan keperawatan dalam pendokumentasian asuhan keperawatan yang kurang baik yaitu sebanyak $75,0 \%$.

Sedangkan responden memiliki kinerja asuhan keperawatan dalam pendokumentasian asuhan keperawatan yang berkatagori baik yaitu sebanyak 25\%.Kinerja perawat merupakanpencapaian/prestasi seseorang berkenanaan dengan seluruh tugas yang diberikan kepadanya sesuai dengan standar yang berlaku. (Okaisu, 2014). Hasil analisis menunjukkan bahwa gambaran kualitas pendokumentasian asuhan keperawatan di 8 ruang rawat inap di RSUD Kalimantan Tengah berkualitas sebanyak 124 rekam medis (55,9\%), dan tidak berkualitas sebanyak 98 rekam medis (44,1\%).Penelitian ini dilakukan di CVBC RSUP

Prof. Dr. R. D. Kandou Manado pada bulan Februari 2015 mengenai hubungan perilaku perawat dengan pendokumentasian asuhan keperawatan. Hasil analisis karateristik responden menurut usia adalah rentang usia 21-30 tahun adalah 14 perawat dengan persentase 35\%, usia 31-40 tahun adalah 20 perawat dengan persentase 50\% serta usia lebih dari 40 tahun 6 perawat dengan persentase $15 \%$. Pada tahapan dewasa muda individu telah mulai menata kehidupannya untuk mencapai kestabilan. Hal senada diungkapkan pula oleh Potter dan Perry (2005) bahwa seseorang yang telah memasuki tahap dewasa muda diharuskan untuk menentukan tanggung jawab, mencapai kestabilan dalam hal pekerjaan, dan memiliki hubungan dalam tahap yang lebih intim. Oleh karena itu pada tahap usia dewasa muda seharusnya perawat memiliki perilaku yang stabil dan pencapaian perilaku baik.

Hasil penelitian menunjukkan responden dengan jenis kelamin perempuan sama banyak dengan responden dengan jenis kelamin laki-laki. Dimana responden berjenis kelamin perempuan dan jenis kelamin laki-laki berjumlah 20 perawat dengan persentase masing-masing $50 \%$. Hasil penelitian menunjukkan responden dengan masa kerja kurang dari 3 tahun berjumlah 20 orang dan masa kerja lebih dari 3 tahun berjumlah 20 orang dengan persentase masingmasing 50\%. Hasil penelitian menunjukkan responden dengan tingkat pendidikan DIII keperawatan berjumlah 18 orang dengan persentase 45\% dan S.Kep Ns berjumlah 22 orang dengan persentase 55\%. Menurut Notoatmodjo, (2007) Perilaku adalah tindakan atau aktivitas 
dari manusia itu sendiri yang mempunyai bentangan yang sangat luas antara lain : berjalan, berbicara, menangis, tertawa, bekerja, kuliah, menulis, membaca, dan sebagainya. Dari uraian ini dapat disimpulkan bahwa yang dimaksud perilaku manusia adalah semua kegiatan atau aktivitas manusia, baik yang diamati langsung, maupun yang tidak dapat diamati oleh pihak luar. Perilaku perawat menurut Videbeck (2008), Burnard( 2008) dan Gunarsa, (2008) adalah perilaku terapeutik yang melibatkan semua unsur. Perilaku perawat menurut Kusnanto, (2004) harus dilandasi oleh aspek moral yang meliputi hal-hal berikut : Beneficience yang berarti sebagai profesional perawat harus selalu mengupayakan tiap keputusan yang dibuat berdasarkan keinginan untuk melakukan yang terbaik dan tidak merugikan klien.

Adil yang berarti tidak mendiskriminasikan klien berdasarkan agama, ras, sosial budaya, keadaan ekonomi, dan sebagainya tetapi memperlakukan klien sebagai individu yang memerlukan bantuan dengan keunikan yang dimiliki. Fidelity yang berarti bahwa perilaku caring, selalu berusaha menepati janji, memberikan harapan yang memadai, memiliki komitmen moral serta memperhatikan kebutuhan spiritual klien. Menurut teori perubahan perilaku yang dikembangkan oleh Lawrence Green dalam Noorkasiani (2009) menyebutkan bahwa perubahan perilaku disebabkan oleh dua faktor utama yaitu faktor perilaku dan faktor non-perilaku.

Faktor perilaku ditentukan oleh tiga kelompok faktor, yaitu; faktor predisposisi (predispocing factor), faktor pendukung (enabling factor), dan faktor penguat (reinforcing factor).Gambaran Karakteristik Demografi umur, didapatkan perawat dengan usia $<30$ tahun sama dengan perawat yang berusia $\geq 30$ tahun, artinya perawat pelaksana diruang rawat inap RSUD Pasar Rebo jumlahnya sama antara perawat yang muda dan perawat yang usia lebih tua. Jenis Kelamin perawat pelaksana yang bekerja di ruang rawat inap RSUD Pasar Rebo menunjukkan perawat pelaksana berjenis kelamin perempuan $91.25 \%$ laki-laki $8.75 \%$. Tingkat pendidikan D-III keperawatan lebih banyak 91.25\%, dibandingkan pendidikan Sarjana keperawatan $8.75 \%$. Lama kerja perawat pelaksana 25\% dengan lama kerja $<3$ tahun, 53.75\% dengan lama kerja 3-10 tahun serta $21.25 \%>10$ tahun.

Status Kepegawaian PNS 3.75\%, dan non PNS 96.25\%. Sebagian besar perawat pelaksana status kepegawaiannya adalah non PNS (walaupun bukan PNS) penghasilan (honor) mereka cukup memadai, pengakuan beberapa perawat pelaksana non PNS yang bekerja > 3 tahun), dan hanya 3 orang perawat pelaksana yang berstatus kepegawaian PNS. Gambaran 
motivasi perawat pelaksana dalam melaksanakan asuhan keperawatan membutuhkan dorongan dan dukungan baik secara internal maupun eksternal, termasuk atasannya yaitu kepala ruangan. Hasil penelitian yang dilakukan terhadap 80 perawat pelaksana menunjukan bahwa motivasi intrinsik (kepuasan $=$ satisfiers) perawat pelaksana tidak baik sebesar $52.5 .2 \%$, dan faktor ekstrinsik (ketidakpuasan $=$ dissatisfiers) perawat kurang baik $48.75 \%$.

Kurang baiknya motivasi perawat pelaksana dapat dilihat $60.0 \%$ perawat pelaksana mengatakan tidak pernah menerima insentif tambahan untuk pelaksanaan pendokumentasian, $46.0 \%$ perawat mengatakan tidak pernah menerima insentif untuk pengisian pendokumentasian diberikan dengan adil, $49.0 \%$ perawat mengatakan kadang-kadang gaji yang diterima tidak sesuai dengan pekerjaan dan dokumentasi yang dilakukan, $68.0 \%$ perawat mengatakan jarang mendapatkan kesempatan untuk meningkatkan kemampuan dalam Post conference adalah komunikasi katim dan perawat pelaksana tentang hasil kegiatan sepanjang shift dan sebelum operan kepada shift berikut. Isi post conference adalah hasil askep tiap perawatan dan hal penting untuk operan (tindak lanjut). Post conference dipimpin oleh katim atau Pj tim (Modul MPKP, 2006) Menurut asumsi peneliti, tidak optimalnya pelaksanaan post conference mungkin disebabkan oleh belum semua perawat memahami apa yang harus dilakukan saat pre dan post conference dan menganggap kegiatan itu membuang-buang waktu. Sehingga perawat merasa tidak perlu melakukan kegiatan post conference.

Menurut peneliti, untk mengatasi hal ini perlu dilaksanakannya pelatihan kepada tenaga perawat tentang pre post conference.Motivasi dalam penelitian ini dikembangkan berdasarkan teori Mc Clelland yang dikelompokkan menjadi tiga kebutuhan manusia yaitu kebutuhan kekuasaan, kebutuhan afiliasi dan kebutuhan prestasi (Pitman, 2011). Menurut Mc Clelland dalam Mangkunegara (2005) kebutuhan berafiliasi adalah dorongan untuk berinteraksi dengan orang lain. Kebutuhan ini dapat diwujudkan melalui keikutsertaan seseorang dalam suatu organisasi atau perkumpulan-perkumpulan. Kebutuhan afiliasi pada prinsipnya agar dirinya itu diterima dan dianggap menjadi bagian dari kelompok tersebut. Kebutuhan kekuasaan tampak pada perawat yang ingin mempengaruhi orang lain, senang berkompetisi, mandiri, aktif menjalankan kebijakan organisasi, selalu menjaga prestasi, reputasi, serta posisinya (Suarli \& Yayan, 2008). 
Perawat sebagian besar mempunyai pendidikan D3keperawatan. Pendidikan merupakan faktor tidak langsung yang berpengaruh pada kinerja (Ilyas,2002). Hasil penelitian menunjukkan bahwa tidak ada hubungan bermakna antara tingkat pendidikan dengan pelaksanaan perencanaan pulang. Menurut Hermawati (2002) dan Panjaitan (2002), tidak adahubungan yang bermakna antara tingkat pendidikan dengan kinerja.

Farida (2001) menyebutkan tidak ada hubungan yang bermakna antara pendidikan dengan pelaksanaan proses keperawatan. Hariyati, Afifah, dan Handiyani (2008), menyatakan tidak ada hubungan jenis pendidikan dengan persepsi terhadap pelaksanaan discharge planning.Perawat sebagian besar sudah menikah. Karyawan yang sudah menikah menilai pekerjaan sangat penting karena dia sudah memiliki tanggung jawab sebagai kepala keluarga (Sopiah, 2008). Robbins(2006) menyatakan bahwa suatu pernikahan akan memaksakan peningkatan tanggung jawab yang dapat membuat suatu pekerjaan yang tetap menjadi lebih berharga dan lebih penting.

Hasil penelitian menunjukkan tidak ada hubungan antara status perkawinan dengan pelaksanaan perencanaan pulang. Norman (2004) menyatakan bahwa tidak ada hubungan bermakna antara status pernikahan dengan pelaksanaan pelayanan keperawatan. Farida(2001) menyebutkan tidak ada hubungan bermakna antara status perkawinan dengan pelaksanaan proses keperawatan.Perawat sebagian besar mempunyai masa kerja 1-9 tahun. Menurut Sopiah (2008), belum ada bukti,semakin lama seseorang bekerja maka tingkat produktivitasnya akan meningkat. Hasil penelitian menunjukkan tidak ada hubungan antara masa kerja dengan pelaksanaan perencanaan pulang.

Farida(2001) menyebutkan tidak ada hubungan yang bermakna antara lama kerja dengan pelaksanaan proses keperawatan. Ini sejalan dengan Sopiah(2008), belum ada bukti semakin lama seseorang bekerja maka tingkat produktivitasnya akan meningkat.Hubungan Personil Perencanaan Pulang dengan Pelaksanaan Perencanaan Pulang Hasil penelitian didapatkan ada hubungan antara personil perencanaan pulang dengan pelaksanaan perencanaan pulang. Menurut Poglitsch, et al.(2011), yang menyatakan personil perencanaan pulang mempengaruhi pelaksanaan perencanaan pulang. 
Menurut Nosbusch, Weiss, dan Bobay(2011), salah satu tantangan yang dihadapi oleh perawat dalam perencanaan pulang pada pasien dengan perawatan akut merupakan kebingungan peran dan tidak terlihatnya peran staf perawat dalam perencanaan pasien pulang. Menurut Baron, et al. (2008), tanggung jawab pada perencanaan pulang di rumah sakit adalah tanggung jawab staf keperawatan. Pendapat dari Owyoung(2010), bahwa perawat bertanggung jawab untuk bekerjasama dengan pasien dan penyedia layanan kesehatan di masyarakat, membangun pelayananrujukan kesehatan, dan memeriksa pasien yang masuk setiap hari, serta memulangkan dengan menentukan yang akan memerlukan perawatan diluar rumah sakit.

Hubungan Keterlibatan dan Partisipasi dengan Pelaksanaan Perencanaan Pulang Hasil penelitian menunjukkan bahwa ada hubungan yang bermakna antara keterlibatan dan partisipasi dengan pelaksanaan perencanaan pulang. Menurut Poglitsch, et al. (2011), menyatakan keterlibatan dan partisipasi mempunyai pengaruh terhadap pelaksanaan perencanaan pulang. Frampton (2011)memaparkan bahwa keterlibatan multi profesional secara dini sangat penting dalam perencanaan pulang yang efektif. Menurut Holland dan Heman(2011) bahwa keberhasilan standarisasi proses perencanaan pulang merupakan kerjasama tim multidisiplin

\section{Saran dan kesimpulan}

Ada hubungan antara faktor personil perencanaan pulang, keterlibatan dan partisipasi, komunikasi,perjanjian dan konsensus dengan pelaksanaan perencanaan pulang. Tidak ada hubungan antara faktor karakteristik perawat dan waktu dengan pelaksanaan perencanaan pulang. Faktor yang paling berpengaruh pada pelaksanaan perencanaan pulang pada perawat adalah faktor perjanjian dan konsensus. Rekomendasi penelitian ini yaitu adanya SOP dan alur yang jelas untuk mengatur peran personil perencanaan pulang, mengatur keterlibatan, dan partisipasi orang-orang yang terlibat dalam pelaksanaan perencanaan pulang, serta mengatur perjanjian dan konsensus dalam pelaksanaan perencanaan pulang. Saran lain yaitu memotivasi perawat melakukan komunikasi dan hubungan profesional dengan teman sejawat, dokter, pasien dan keluarga, serta petugas kesehatan di masyarakat dalam pelaksanaan perencanaan pulang (HW, JS,HP) 


\section{Daftar Pustaka}

Butar-Butar, J., \& Simamora, R. H. (2016). Hubungan Mutu Pelayanan Keperawatan dengan Tingkat Kepuasan Pasien Rawat Inap di RSUD Pandan Kabupaten Tapanuli Tengah. Jurnal Ners Indonesia, 6(1), 50-63.

Moran, G., Semansky, R., Quinn, E., Noftsinger, R., \&Koenig, T. (2005). Evaluability assessment ofdischarge planning and the prevention ofhomelessness. Rockville: WESTAT.

NCSS. (2006). Care and discharge planning: A guidefor service providers. Singapore: National Councilof Social Service. (Serial No: 032/SDD19/DEC06)

Norman, R. (2004). Faktor-faktor yang berkontribusi dalam pelaksanaan pelayanan keperawatandi ruang rawat inap RSPAD Gatot Subroto Jakarta(Tesis, tidak dipublikasikan). FIK UI, Jakarta.

Nosbusch, J.M., Weiss, M.E., \& Bobay, K.L. (2011).An integrated review of the literature on challenges confronting the acute care staff nurse in dischargeplanning. Journal of Clinical Nursing, 20 (5-6),754-774. Publisher: Wiley-Blackwell.

Owyoung, P. (2010). Role of a nurse in dischargeplanning. Diperoleh dari http://www.ehow.com/a b ou t _ $\begin{array}{llllllllllll}6 & 3 & 6 & 7 & 1 & 2 & 4\end{array}$, r o le- nu r s e-d is c ha rg epanning.html.

Panjaitan, R. (2002). Hubungan efektifitas kepemimpinan kepala ruang dengan kinerjaperawat pelaksana di ruang rawat inap RSPAD Gatot Subroto (Tesis, tidak dipublikasikan). FIK

Poglitsch, L.A., Emery, M., \& Darragh, A. (2011). Aqualitative study of the determinants of successful discharge for older adult inpatients. Journal of American Physical Therapy Association. (ISSN1538-6724).

Simamora, R. H. (2005). Hubungan Persepsi Perawat Pelaksana Terhadap Penerapan Fungsi Pengorganisasian Yang Dilakukan Oleh Kepala Ruangan Dengan Kinerjanya Diruang Rawat Inap RSUD Koja Jakarta Utara (Doctoral dissertation, Tesis FIK UI, Tidak dipublikasikan)

Supriyatna, Y. (2003). Hubungan antara gaya kepemimpinan kepala ruang dengan produktifitas kerja perawat pelaksana di Rumah Sakit PusatPertamina Jakarta (Tesis, tidak dipublikasikan).Fakultas Ilmu Keperawatan Universitas Indonesia,Jakarta.

Swansburg, R.C. (2000). Pengantar kepemimpinan dan manajemen keperawatan. Alih bahasa Suharyati Samba (Editor Monica Ester). Jakarta: EGC.

Tomura, H., Yamamoto, M.N., Nagata, Murashima, S.,\& Suzuki, S. (2011). Creating an agreed discharge:Discharge planning for clients with high careneeds. J Clin Nurs, 20 (3-4), 444453.Doi:10.1111/j.1365-2702.2010.03556.x.WHO. (2005).Pedoman perawatan pasien. Alih bahasa Monica Ester (Editor edisi bahasa Indonesia: EstyWahyuningsih, Nike Budhi Subekti). Jakarta:Penerbit Buku Kedokteran EGC. 
UI, Jakarta.Papalia, D.E., Olds, S.W., \& Feldman, R.D. (2009).Human development perkembangan manusia(Edisi kesepuluh). Jakarta: Salemba Humanika. 